GHIRALDELLI, Felipe Vittig. LEITE, Ruano Fernando da Silva. As atribuições de polícia judiciária no bojo das investigações de homicídios dolosos praticados por policiais militares contra civis. Revista Eletrônica Direito e Política, Programa de Pós-Graduação Stricto Sensu em Ciência Jurídica da UNIVALI, Itajaí, v.11, n.2, 2ㅇ quadrimestre de 2016. Disponível em: www.univali.br/direitoepolitica - ISSN 1980-7791.

\title{
AS ATRIBUIÇÕES DE POLÍCIA JUDICIÁRIA NO BOJO DAS INVESTIGAÇÕES DE HOMICÍDIOS DOLOSOS PRATICADOS POR POLICIAIS MILITARES CONTRA CIVIS
}

\author{
THE DUTIES OF JUDICIAL POLICE IN BUNT OF HOMICIDE \\ INVESTIGATION INTENTIONAL COMMITED BY POLICE MILITARY \\ AGAINST CIVILIAN
}

Felipe Vittig Ghiraldelli ${ }^{1}$

Ruano Fernando da Silva Leite ${ }^{2}$

SÚMARIO: Introdução; 1. Dos crimes militares; 2. Breves considerações sobre o delito de homicídio; 3. Tratativa das alterações legislativas 4. Do atual tratamento pelos estados; 5. Da divergência doutrinária e jurisprudencial sobre a atribuição; 6. Do tratamento internacional sobre a questão; Considerações finais; Referências das fontes citadas

\section{RESUMO}

O presente trabalho tem por escopo analisar o conflito de atribuições de polícia judiciária nas investigações dos crimes de homicídios dolosos praticados por policiais militares contra vítimas civis. Diante da atecnia das sucessivas alterações legais e da atual diversidade de tratamento da questão em cada Estado membro, se faz necessária uma abordagem acurada, condizente com a Constituição Federal e com as convenções internacionais de direitos humanos.

\footnotetext{
${ }_{1}$ Pós-graduado em Direito pela Uniasselvi, graduado pela Unifeg, Professor de Processo Penal da Unifeg (Centro Universitário da Fundação Educacional Guaxupé). Aprovado no concurso de Delegado da Polícia Civil do Estado da Bahia. E-mail: felipeghiraldelli@gmail.com

2 Pós-graduado em Ciências Penais pela Universidade Anhanguera. Bacharel em Direito pela Universidade Estadual do Sudoeste da Bahia. Servidor do Ministério Público do Estado da Bahia. Aprovado nos concursos de Promotor de Justiça e Delegado de Polícia Civil do Estado da Bahia, além de outros. Editor do blog http://palavradejurista.blogspot.com.br/.E-mail: ruanoleite@msn.com
} 

no bojo das investigações de homicídios dolosos praticados por policiais militares contra civis. Revista Eletrônica Direito e Política, Programa de Pós-Graduação Stricto Sensu em Ciência Jurídica da UNIVALI, Itajaí, v.11, n.2, 2ㅇ quadrimestre de 2016. Disponível em: www.univali.br/direitoepolitica - ISSN 1980-7791.

PALAVRAS-ChAVe: Processo penal. Polícia Judiciária. Polícia Civil. Polícia Militar. Homicídios dolosos.

\section{ABSTRACT}

This work has the scope to analyze the conflict of judicial police powers in investigations of crimes of murder committed by military police against civilians. Before the atecnia successive legal changes and the current issue of treatment of diversity in each Member State , if an accurate approach is needed, consistent with the Federal Constitution and international human rights conventions .

Keywords: Criminal proceedings. Judiciary Police. Civil police. Military police. Unlawful killings .

\section{INTRODUÇÃO}

Conforme indicam as últimas pesquisas ${ }^{3}$, as polícias brasileiras, infelizmente, ainda apresentam alarmantes índices de letalidade.

É bem verdade que muitas mortes ocorrem sob o amparo da lei, em virtude do confronto com uma criminalidade cada vez mais armada e igualmente letal. Porém, não tem sido raros os casos de execuções praticadas por policiais e que merecem a devida repressão.

No derredor desta questão encontra-se o problema do conflito de atribuições de polícia judiciária ${ }^{4}$ no que pertine à investigação dos homicídios dolosos praticados por policiais militares em face de vítimas civis.

3 http://www1.folha.uol.com.br/cotidiano/2015/10/1689789-mortes-por-policiaisno-pais-em-um-ano-equivalem-a-um-11-de-setembro.shtml

4 Palavra utilizada aqui com o mesmo sentido de polícia investigativa, sem obstar do entendimento que diferencia ambas as expressões. 
Isto porque, à margem das sucessivas alterações legislativas e das infindáveis discussões doutrinárias, ainda persiste a dúvida sobre qual a polícia (civil ou militar) é realmente competente para presidir as investigações naqueles casos.

O problema se intensifica quando, na prática, se constata que cada Estado membro adota um entendimento, ou, pior, que a atribuição é definida discricionariamente conforme o caso concreto.

Para resolver o problema, inicialmente, o estudo buscou compreender o conceito de crime militar e diagnosticar a natureza jurídica do delito de homicídio, delimitando-se o objeto. Em seguida, foi analisada a sucessão das leis pertinentes ao assunto e realizado o mapeamento, por amostragem, do atual cenário nos diferentes Estados. Por fim, o trabalho enfrentou os fundamentos das diferentes correntes doutrinárias e jurisprudenciais, além de abordar o tratamento da questão no âmbito internacional.

Como não poderia ser diferente, a pesquisa foi conduzida através das lentes constitucional e convencional.

\section{DOS CRIMES MILITARES}

Em plena ditadura militar, através do Ato institucional número 16, de 14 de outubro de 1969 , combinado com o $\S 1^{\circ}$ do art. $2^{\circ}$, do Ato Institucional $n^{\circ} 5$, de 13 de dezembro de 1968, os Ministros da Marinha de Guerra, do Exército e da Aeronáutica Militar decretaram o Código Penal Militar, o qual encontra-se vigente até a presente data através do Dec-Lei 1.001/69. 
GHIRALDELLI, Felipe Vittig. LEITE, Ruano Fernando da Silva. As atribuições de polícia judiciária no bojo das investigações de homicídios dolosos praticados por policiais militares contra civis. Revista Eletrônica Direito e Política, Programa de Pós-Graduação Stricto Sensu em Ciência Jurídica da UNIVALI, Itajaí, v.11, n.2, 2ㅇ quadrimestre de 2016. Disponível em: www.univali.br/direitoepolitica - ISSN 1980-7791.

O referido Código foi parcialmente recepcionado pela Constituição Federal e, atualmente, satisfaz adequadamente o comando do art. 124 da Carta Republicana que prevê a tipificação dos crimes militares através de norma ordinária, nos seguintes termos:

Art. 124. À Justiça Militar compete processar e julgar os crimes militares definidos em lei.

Parágrafo único. A lei disporá sobre a organização, o funcionamento e a competência da Justiça Militar.

Importante observar que esta lei é aplicada para os militares em geral, pertencentes às Forças Armadas (Marinha, Exercito e Aeronáutica), e também aos militares estaduais, pertencentes às Policias Militares e Bombeiros Militares estaduais, por força do art. 22 do Código Penal Militar combinado com o art. 42 da Constituição Federal, que preveem, respectivamente, que:

Art. 22. É considerada militar, para efeito da aplicação deste Código, qualquer pessoa que, em tempo de paz ou de guerra, seja incorporada às forças armadas, para nelas servir em posto, graduação, ou sujeição à disciplina militar.

Art. 42 Os membros das Polícias Militares e Corpos de Bombeiros Militares, instituições organizadas com base na hierarquia e disciplina, são militares dos Estados, do Distrito Federal e dos Territórios.

No mesmo sentido é a disposição do art. 125, § 40, da Constituição Federal quando determina que "compete à Justiça Militar estadual processar e julgar os militares dos Estados, nos crimes militares definidos em lei". 
GHIRALDELLI, Felipe Vittig. LEITE, Ruano Fernando da Silva. As atribuições de polícia judiciária no bojo das investigações de homicídios dolosos praticados por policiais militares contra civis. Revista Eletrônica Direito e Política, Programa de Pós-Graduação Stricto Sensu em Ciência Jurídica da UNIVALI, Itajaí, v.11, n.2, 2ㅇ quadrimestre de 2016. Disponível em: www.univali.br/direitoepolitica - ISSN 1980-7791.

Assim sendo, está com razão o doutrinador Célio Lobão ${ }^{5}$ quando esclarece que:

Crime militar é a infração penal prevista na Lei Penal Militar que lesiona bens ou interesses vinculados à destinação constitucional das instituições militares, as suas atribuições legais, ao seu funcionamento, à sua própria existência, no aspecto particular da disciplina, da hierarquia, da proteção à autoridade militar, e ao serviço militar.

Vale dizer que o próprio Código Penal Militar fez uma interpretação autêntica dos crimes militares através das normas dos arts. 90 e 10 ao estabelecer que:

Art.90 Consideram-se crimes militares, em tempo de paz:

I - os crimes de que trata êste Código, quando definidos de modo diverso na lei penal comum, ou nela não previstos, qualquer que seja o agente, salvo disposição especial;

II - os crimes previstos neste Código, embora também o sejam com igual definição na lei penal comum, quando praticados:

a) por militar em situação de atividade ou assemelhado, contra militar na mesma situação ou assemelhado;

b) por militar em situação de atividade ou assemelhado, em lugar sujeito à administração militar, contra militar da reserva, ou reformado, ou assemelhado, ou civil;

c) por militar em serviço ou atuando em razão da função, em comissão de natureza militar, ou em formatura, ainda que fora do lugar sujeito à

${ }^{5}$ LOBÃO, Célio. Comentários ao Código Penal Militar: Vol. 1 Parte Geral. Rio de Janeiro: Forense, 2011, p.31 
GHIRALDELLI, Felipe Vittig. LEITE, Ruano Fernando da Silva. As atribuições de polícia judiciária no bojo das investigações de homicídios dolosos praticados por policiais militares contra civis. Revista Eletrônica Direito e Política, Programa de Pós-Graduação Stricto Sensu em Ciência Jurídica da UNIVALI, Itajaí, v.11, n.2, 2ㅇ quadrimestre de 2016. Disponível em: www.univali.br/direitoepolitica - ISSN 1980-7791.

administração militar contra militar da reserva, ou reformado, ou civil;

d) por militar durante o período de manobras ou exercício, contra militar da reserva, ou reformado, ou assemelhado, ou civil;

e) por militar em situação de atividade, ou assemelhado, contra o patrimônio sob a administração militar, ou a ordem administrativa militar;

III - os crimes praticados por militar da reserva, ou reformado, ou por civil, contra as instituições militares, considerando-se como tais não só os compreendidos no inciso I, como os do inciso II, nos seguintes casos:

a) contra o patrimônio sob a administração militar, ou contra a ordem administrativa militar;

b) em lugar sujeito à administração militar contra militar em situação de atividade ou assemelhado, ou contra funcionário de Ministério militar ou da Justiça Militar, no exercício de função inerente ao seu cargo;

c) contra militar em formatura, ou durante o período de prontidão, vigilância, observação, exploração, exercício, acampamento, acantonamento ou manobras;

d) ainda que fora do lugar sujeito à administração militar, contra militar em função de natureza militar, ou no desempenho de serviço de vigilância, garantia e preservação da ordem pública, administrativa ou judiciária, quando legalmente requisitado para aquêle fim, ou em obediência a determinação legal superior.

Art. 10. Consideram-se crimes militares, em tempo de guerra:

I - os especialmente previstos neste Código para o tempo de guerra;

II - os crimes militares previstos para o tempo de paz;

III - os crimes previstos neste Código, embora também o sejam com igual definição na lei penal comum ou especial, quando praticados, qualquer que seja o agente: 

no bojo das investigações de homicídios dolosos praticados por policiais militares contra civis. Revista Eletrônica Direito e Política, Programa de Pós-Graduação Stricto Sensu em Ciência Jurídica da UNIVALI, Itajaí, v.11, n.2, 2ㅇ quadrimestre de 2016. Disponível em: www.univali.br/direitoepolitica - ISSN 1980-7791.

a) em território nacional, ou estrangeiro, militarmente ocupado;

b) em qualquer lugar, se comprometem ou podem comprometer a preparação, a eficiência ou as operações militares ou, de qualquer outra forma, atentam contra a segurança externa do País ou podem expô-la a perigo;

IV - os crimes definidos na lei penal comum ou especial, embora não previstos neste Código, quando praticados em zona de efetivas operações militares ou em território estrangeiro, militarmente ocupado.

Dessa forma, observa-se que o Código Castrense adotou o critério ratione legis, sendo crime militar aquele descrito pela norma. Em outras palavras, exige-se que o fato esteja tipificado no Código Penal Militar e que se amolde a uma das hipóteses dos artigos 90 e 10 do CPM.

Vale lembrar, ainda, que os crimes militares tipificados no artigo 90 do Código Penal Militar se dividem em crimes propriamente e impropriamente militares. Os primeiros, descritos no inciso I daquele artigo tem como sujeito ativo do delito somente um militar, não existindo correspondência na lei penal comum. Ademais, lesiona bens e interesses das instituições militares atingindo a hierarquia e a disciplina. Já os crimes militares impróprios, previstos no inciso II, ao contrário, possuem correspondentes no Código Penal Comum e tem como sujeito ativo o militar, desde que encontre-se em uma das condições descritas nas respectivas alíneas.

\section{BREVES CONSIDERAÇÕES SOBRE O DELITO DE HOMICÍDIO.}



no bojo das investigações de homicídios dolosos praticados por policiais militares contra civis. Revista Eletrônica Direito e Política, Programa de Pós-Graduação Stricto Sensu em Ciência Jurídica da UNIVALI, Itajaí, v.11, n.2, 2ㅇ quadrimestre de 2016. Disponível em: www.univali.br/direitoepolitica - ISSN 1980-7791.

O delito de homicídio, como é de curial sabença, encontra-se tipificado no artigo 121 do Código Penal, cujo preceito primário se resume à conduta de "matar alguém".

Para Paulo Cesar Busato6, "matar é ceifar a vida, ato que presume a existência desta. No homicídio se trata da vida independente, extrauterina, e não mais a vida em formação, como no aborto".

De forma mais amiúde, Rogério $\mathrm{Greco}^{7}$ leciona que o homicídio só pode ocorrer a partir do inicio do parto, encerrando-se com a morte da vítima, com o inicio do trabalho do parto, com a dilatação do colo do útero ou com o rompimento da membrana aminiótica, sendo o parto normal, ou a partir das incisões das camadas abdominais, no parto cesariana, até a morte do ser humano que ocorre com a morte encefálica.

Ocorre que também há a tipificação do homicídio doloso no artigo 205 do Código Penal Militar, de modo que, por muito tempo e de forma uníssona, foi considerado um crime militar impróprio, sujeito à competência Castrense, mesmo quando praticado por policiais militares em atividade de natureza civil.

Em verdade, o problema objeto do presente trabalho somente surgiu em 1996 com as alterações legislativas que serão vistas no próximo capítulo, as quais somente atingiram o crime de homicídio doloso.

\footnotetext{
${ }^{6}$ BUSATO, Paulo César. Direito Penal: parte especial 1. São Paulo: Atlas, 2014. p.20.
}

7 GRECO, Rogério. Curso de Direito Penal: parte especial II. 11 a Ed. Niterói: Impetus,2015. p. 137. 
Vale salientar que, apesar de o Código Penal Militar também prever o delito de homicídio culposo no art. 206 do Código Penal Militar, não há dúvidas de que, pelo menos do ponto de vista normativo, tal conduta continuou sujeita à Jurisdição Militar, por não ter sido afetada pelas modificações. Por isso tal modalidade não é objeto de estudo nesta pesquisa.

Ademais, também não será objeto de apontamentos neste artigo a ressalva realizada pela lei 12.432/11 que, alterando o art. 90, paragrafo único, do Código Penal Militar, manteve incólume a competência e atribuição militar para a apuração dos crimes dolosos contra a vida: "(...) quando praticados no contexto de ação militar realizada na forma do art. 303 da Lei $n^{\circ}$ 7.565, de 19 de dezembro de 1986 - Código Brasileiro de Aeronáutica".

\section{TRATATIVA DAS ALTERAÇÕES LEGISLATIVAS}

Conforme mencionado, em 1996, foi editada a Lei Federal no 9.299, mais conhecida como a "Lei Rambo", promovendo alterações no Código Penal Militar e no Código de Processo Penal Militar.

Essencialmente, a Lei Rambo modificou o paragrafo único do art. 90 do Código Penal Militar, estabelecendo que os crimes, "quando dolosos contra a vida e cometidos contra civil, serão da competência da justiça comum".

Desta forma, os homicídios dolosos praticados por militares contra civis deixaram de ser da competência da Justiça Castrense, passando, a partir de então, a ser julgados pela justiça comum. 

no bojo das investigações de homicídios dolosos praticados por policiais militares contra civis. Revista Eletrônica Direito e Política, Programa de Pós-Graduação Stricto Sensu em Ciência Jurídica da UNIVALI, Itajaí, v.11, n.2, 2ㅇ quadrimestre de 2016. Disponível em: www.univali.br/direitoepolitica - ISSN 1980-7791.

Essa esdrúxula situação ocorreu, sobretudo, porque a Lei nº 9.299/96 alterou a competência sem, contudo, afastar a natureza militar (imprópria) do crime de homicídio prevista no art. 205 do CPM. O grande problema é que a Constituição dizia que competia à Justiça Militar os crimes militares definidos em lei, em razão do que se instalou grande controvérsia sobre a constitucionalidade da alteração legislativa no que tange a competência.

Em 2004, então, através da reforma do Poder Judiciário levada a efeito por meio da Emenda Constitucional no 45, a competência da Justiça Comum para os crimes dolosos contra a vida cometidos contra civil foi corroborada com a alteração do art. $125, \S^{\circ}{ }^{\circ}$, da Constituição Federal, o qual passou a ter a seguinte redação:

$\S 40$ Compete à Justiça Militar estadual processar e julgar os militares dos Estados, nos crimes militares definidos em lei e as ações judiciais contra atos disciplinares militares, ressalvada a competência do júri quando a vítima for civil, cabendo ao tribunal competente decidir sobre a perda do posto e da patente dos oficiais e da graduação das praças.

Essa alteração constitucional foi relevante, portanto, para pacificar a questão da competência, mas, novamente, não tratou expressamente sobre atribuição de polícia judiciária para o delito de homicídio praticado por militares, que, em tese, continuava sendo acidentalmente militar.

É importante notar que esta discussão, apesar de tão debatida, continua atualmente indefinida. A situação posta é muito relevante e, por envolver direitos fundamentais, deve ser solucionada de forma breve e através de interpretações que reflitam as normas da Constituição e dos tratados internacionais de direitos humanos. 
GHIRALDELLI, Felipe Vittig. LEITE, Ruano Fernando da Silva. As atribuições de polícia judiciária no bojo das investigações de homicídios dolosos praticados por policiais militares contra civis. Revista Eletrônica Direito e Política, Programa de Pós-Graduação Stricto Sensu em Ciência Jurídica da UNIVALI, Itajaí, v.11, n.2, 2ㅇ quadrimestre de 2016. Disponível em: www.univali.br/direitoepolitica - ISSN 1980-7791.

\section{DO ATUAL TRATAMENTO PELOS ESTADOS}

Diante da nebulosidade instalada, os Estados membros passaram a adotar procedimentos diversos.

No Estado de São Paulo, o qual possui maior efetivo de policiais militares do Brasil, com cerca de oitenta e sete mil policiais, a atribuição foi, inicialmente, fixada pela Resolução no $110 / 10^{8}$, da Secretária de Segurança Pública, ao determinar que "nos crimes dolosos contra a vida, praticados por policiais militares contra civis,

8 Resolução SSP-110, de 19-07-2010. Disciplina o procedimento em ocorrências que envolvam crimes dolosos contra a vida, praticados por policiais militares contra civis.

Considerando a necessidade de padronizar o procedimento a ser adotado nas ocorrências que envolvam crimes dolosos contra a vida, praticados por policiais militares, eliminando interpretações geradoras de desinteligências entre a Polícia Civil e a Polícia Militar;

Considerando ser indevida a condução de autores desses crimes, em razão de prisão em flagrante delito, às unidades da Polícia Militar, para a prática de atos de polícia judiciária militar, causando embaraços e prejuízos à imediata coleta de provas e demais providências a cargo da autoridade policial civil, o Secretário da Segurança Pública, resolve:

Artigo $1^{0}$ - Nos crimes dolosos contra a vida, praticados por policiais militares contra civis, os autores deverão ser imediatamente apresentados à autoridade policial civil para as providências decorrentes de atividade de polícia judiciária, nos termos da legislação em vigor (art. 90, parágrafo único do Código Penal Militar e art. 10, $\$ 3^{\circ} \mathrm{c} / \mathrm{c}$ art. 82 do Código de Processo Penal

Militar);

Artigo $2^{\circ}$ - a imediata apresentação determinada pelo artigo anterior não inibe a autoridade de polícia judiciária militar de instaurar, por portaria, Inquérito Policial Militar (IPM) para apuração de eventuais delitos conexos, propriamente militares, dada a imperiosa cisão das ações penais no concurso de crimes comuns e militares, a teor do disposto no art. 79, inc. I, do CPP e art. 102, alínea "a" do CPPM.

Artigo 30 - Esta Resolução passa a vigorar na data de sua publicação.

Antonio Ferreira Pinto Secretário de Estado dos Negócios da Segurança Pública Publicado no Diário Oficial do Estado de São Paulo no dia 21 de Julho de 2010 Caderno Executivo I - Página 12 
GHIRALDELLI, Felipe Vittig. LEITE, Ruano Fernando da Silva. As atribuições de polícia judiciária no bojo das investigações de homicídios dolosos praticados por policiais militares contra civis. Revista Eletrônica Direito e Política, Programa de Pós-Graduação Stricto Sensu em Ciência Jurídica da UNIVALI, Itajaí, v.11, n.2, 2ㅇ quadrimestre de 2016. Disponível em: www.univali.br/direitoepolitica - ISSN 1980-7791.

os autores deverão ser imediatamente apresentados à autoridade policial civil". Entretanto, o Tribunal de Justiça Militar daquele Estado considerou a resolução inconstitucional ${ }^{9}$ e, atualmente, tanto a Polícia Civil quanto a Militar realizam investigações paralelas.

Já no Estado de Minas Gerais, que possui o segundo maior efetivo de policiais militares do Brasil, com aproximadamente cinquenta mil integrantes, curiosamente, não houve a regulamentação pela Secretaria de Segurança Pública, em razão do que cada corporação editou um ato atribuindo para si a "competência". Dessa forma, as atribuições foram fixadas pela Nota Jurídica no 3/2010 10, da Corregedoria da Polícia Civil, e pela Instrução no 05/2012 ${ }^{11}$, da Corregedoria do Tribunal de Justiça Militar e Polícia Militar, ambas concorrentes entre si, de modo que as Polícias Civil e Militar investigam tais delitos autonomamente.

Na Bahia, de outro lado, foi editada a Portaria no 291, de 02 de junho de 2011, pela Secretaria de Segurança Pública, dispondo sobre as diretrizes a serem seguidas no atendimento de local de crime de

9 SÃO PAULO, TRIBUNAL DE JUSTIÇA MILITAR Arguição de Inconstitucionalidade no 001/10. Disponível em: < http://www.jusmilitaris.com.br/uploads/docs/adin_resolucao_ssp_110.pdf >Acesso em 16 de janeiro 2016.

10 MINAS GERAIS. Polícia Civil. Corregedoria Geral de Polícia Civil. Nota Jurídica n. 03/CGPC/2010: Competência para Apuração dos Crimes Dolosos Contra a Vida Praticados por Policiais Militares. Belo Horizonte: Polícia Civil de Minas Gerais, 24 Maio 2010.

11 MINAS GERAIS. Corregedoria do Tribunal de Justiça Militar; MINAS GERAIS, Corregedoria da Polícia Militar. Provimento Conjunto n. 09/2011: Dispõe sobre os Procedimentos de Polícia Judiciária Militar no âmbito da Justiça Miliar do Estado de Minas Gerais. Belo Horizonte: Tribunal de Justiça Militar de Minas Gerais, 08 nov. 2011.7 p. 7 Disponível em:<http://www.tjm.mg.gov.br/images/stories/downloads/corregedoria/proviment o_09-2011.pdf.> Acesso em: 16 janeiro 2016. 

Jurídica da UNIVALI, Itajaí, v.11, n.2, 2ㅇ quadrimestre de 2016. Disponível em: www.univali.br/direitoepolitica - ISSN 1980-7791.

homicídio, a qual trouxe, no parágrafo único do art. $3^{\circ}$, a seguinte disposição, favorável à atribuição da autoridade militar:

\begin{abstract}
Parágrafo Único - Quando houver indícios de envolvimento de policiais militares de serviço na prática do crime de homicídio, assim como militares em atividade, a STELECOM deverá acionar a Corregedoria da Polícia Militar, para que envie preposto daquele órgão ao local da ocorrência, objetivando a tomada das medidas previstas no art. $10, \S 2^{\circ} \mathrm{c} / \mathrm{c}$ art. 12 do Código de Processo Penal Militar.
\end{abstract}

Nada obstante, surpreendentemente, no polêmico "caso Cabula", ocorrido em fevereiro de 2015, em Salvador, quando doze pessoas foram mortas em um confronto com a Polícia Militar, outra providência foi tomada. Na oportunidade, a investigação foi feita pelo Departamento de Homicídios e Proteção à Pessoa-DHPP, da Polícia Civil do Estado da Bahia, contrariando a portaria no 291/11 e demonstrando a insegurança jurídica que ainda paira sobre o tema.

Em sentido inverso, no Rio de Janeiro, foi emitida a Portaria no 553, de 07 de julho de 2011, da PCERJ, a qual determinou a atribuição da Polícia Civil para investigar os homicídios em caso de auto de resistência. O caso "Amarildo", que teve repercussão nacional, é um exemplo investigação realizada pela Polícia Civil daquele Estado.

\title{
5. DA DIVERGÊNCIA DOUTRINÁRIA E JURISPRUDENCIAL SOBRE A ATRIBUIÇÃO
}

Como se percebe, o cerne do debate encontra-se na natureza do delito e na diferenciação entre a atribuição para investigar e a 
GHIRALDELLI, Felipe Vittig. LEITE, Ruano Fernando da Silva. As atribuições de polícia judiciária no bojo das investigações de homicídios dolosos praticados por policiais militares contra civis. Revista Eletrônica Direito e Política, Programa de Pós-Graduação Stricto Sensu em Ciência Jurídica da UNIVALI, Itajaí, v.11, n.2, 2ㅇ quadrimestre de 2016. Disponível em: www.univali.br/direitoepolitica - ISSN 1980-7791.

competência para julgar. E 0 art. $82, \S 2^{\circ}$ do CPPM somente reforça essa constatação com a seguinte redação:

$\S 2^{\circ}$ Nos crimes dolosos contra a vida, praticados contra civil, a Justiça Militar encaminhará os autos do inquérito policial militar à justiça comum.

Sobre o assunto, Jorge Cesar de $\operatorname{Assis}^{12}$ (2007, p. 151 a 153) afirma que não ocorreu uma circunstância exclusória da natureza militar do crime doloso de homicídio e justifica o seu raciocínio ao asseverar que o homicídio doloso não deixou de ser crime militar impróprio, apesar da lei 9.299/96 inserir o paragrafo único do art. $9^{\circ}$ do Código Penal Militar e alterar o art. 82 do Código de Processo Penal Militar.

Para o referido autor ${ }^{13}$ :

[...] a Emenda constitucionalizou o deslocamento do julgamento dos crimes dolosos contra a vida, porém em nenhum momento retirou-lhe a natureza do crime militar, sendo possível afirmar que esta é uma hipótese em que a Justiça Comum processa e julga crime militar, contrariando o principio da especialidades.

Por fim, Jorge Cesar de Assis ${ }^{14}$ conclui que:

Conquanto processado e julgado pela Justiça comum (Tribunal do Júri), é a Justiça Militar quem diz se o crime é, ou não, doloso contra a vida, e desta forma é

12 ASSIS, Jorge Cesar de. Aspectos penais e processuais penais e administrativos. 2a Ed. Curitiba: Juruá, 2007. p. 151 a 153.

13 ASSIS, Jorge Cesar de. Aspectos penais e processuais penais e administrativos. p.157.

14 ASSIS, Jorge Cesar de. Aspectos penais e processuais penais e administrativos. p.166. 
GHIRALDELLI, Felipe Vittig. LEITE, Ruano Fernando da Silva. As atribuições de polícia judiciária no bojo das investigações de homicídios dolosos praticados por policiais militares contra civis. Revista Eletrônica Direito e Política, Programa de Pós-Graduação Stricto Sensu em Ciência Jurídica da UNIVALI, Itajaí, v.11, n.2, 2ㅇ quadrimestre de 2016. Disponível em: www.univali.br/direitoepolitica - ISSN 1980-7791.

a polícia judiciária militar a competente para investigálo, sendo o inquérito policial militar instrumento hábil para tal mister .

No mesmo sentido, Renato Brasileiro de Lima ${ }^{15}$ afirma que dentre as atribuições da Polícia Judiciária Militar existe a atribuição de investigar os crimes militares e os crimes dolosos contra a vida praticados por policiais militares contra civis em respeito ao art. 82, $\S 2^{\circ}$ do CPPM.

O constitucionalista Pedro Lenza ${ }^{16}$, trilhando o escólio de Paulo Tadeu da Rosa, assevera que o Inquérito Policial Militar é o instrumento hábil para apurar o fato e que este, posteriormente, deve ser encaminhado à Justiça Militar para ulterior encaminhamento ao parquet, o qual atua perante a Justiça especializada. Após a manifestação deste, o juiz-auditor deve encaminhar os autos à Justiça comum da Vara do Júri para seguir o rito do Código de Processo Penal.

Já Nestor Távora e Rosmar Rodrigues Alencar ${ }^{17}$ são favoráveis à coexistência de ambos inquéritos, os realizados no âmbito da Policia

15 LIMA. Renato Brasileiro. Manual de Processo Penal. 3aEd. Salvador: Juspodivm, 2015.p. 157.

16 LENZA, Pedro. Direito Constitucional Esquematizado. 16a Ed. São Paulo: Saraiva. 2013. p.756.

17 TÁvORA, Nestor; ALENCAR, Rosmar Rodrigues. Curso de Direito Processual Penal. 9a Ed. Salvador: Juspodivm, 2014. p.111. 
GHIRALDELLI, Felipe Vittig. LEITE, Ruano Fernando da Silva. As atribuições de polícia judiciária no bojo das investigações de homicídios dolosos praticados por policiais militares contra civis. Revista Eletrônica Direito e Política, Programa de Pós-Graduação Stricto Sensu em Ciência Jurídica da UNIVALI, Itajaí, v.11, n.2, 2ㅇ quadrimestre de 2016. Disponível em: www.univali.br/direitoepolitica - ISSN 1980-7791.

Civil em conjunto com o realizado com a policia militar. Coaduna com o mesmo entendimento Renato Marcão ${ }^{18}$.

Ocorre que, trilhando os ensinamentos de Antonio Scarance Fernandes ${ }^{19}$, a melhor interpretação, inclusive com amparo constitucional, somente conduz ao entendimento de que é a Policia Civil que possui a atribuição para investigar estes crimes. Vejamos:

Tornou-se controvertido o $\S 2^{\circ}$, acrescido ao art. 82 . Como a Constituição Federal, em seu art. 144, § 4.0, atribui às polícias civis, dirigidas por delegados de carreira, as funções de polícia judiciária e a apuração de infrações, exceto as militares, a ela incumbiria a investigação dos crimes dolosos contra a vida praticados por militar contra civil, pois deixaram eles de ser crimes militares. Assim, não há motivo algum para ser o inquérito presidido por policiais militares e só ao final serem os autos remetidos pela Justiça Militar à Justiça Comum.

Corrobora este entendimento Jeferson Botelho ${ }^{20} \mathrm{com}$ as seguintes palavras:

Se doloso contra a vida, tentado ou consumado, praticado por militar contra civil, a competência para o processo e julgamento é deslocada para a Justiça Comum. Quanto à apuração dos fatos, muito embora a lei 9.299/96 diga que a Justiça Militar encaminhará o

18 MARCÃo, RenAto. Curso de Processo Penal. São Paulo: Saraiva. 2014. p. 208.

19 FERnANDES, Antonio Scarance. Processo Penal Constitucional. São Paulo: Revista dos Tribunais, 2005. p.160.

20 PEREIRA, Jeferson Botelho. Crimes dolosos contra a vida cometidos por militares contra civis. Minas Gerais, 23 de março de 2009. Disponível em: <http://www.jefersonbotelho.com.br/crimes-dolosos-contra-a-vida-cometidos-pormilitares-contra-civis>. Acesso em: 15 janeiro 2016. 
GHIRALDELLI, Felipe Vittig. LEITE, Ruano Fernando da Silva. As atribuições de polícia judiciária no bojo das investigações de homicídios dolosos praticados por policiais militares contra civis. Revista Eletrônica Direito e Política, Programa de Pós-Graduação Stricto Sensu em Ciência Jurídica da UNIVALI, Itajaí, v.11, n.2, 2ㅇ quadrimestre de 2016. Disponível em: www.univali.br/direitoepolitica - ISSN 1980-7791.

IPM à Justiça Comum, acredito que a norma é inconstitucional, devendo a apuração ficar a cargo da Polícia Civil, considerando que uma vez não sendo mais competência da Justiça Militar, não seria razoável permanecer sob apuração da Justiça Militar.

No mesmo sentido é o magistério do Professor Damásio ${ }^{21}$ ao aduzir que:

A Lei n. 9.299/96 determinou que crimes dolosos contra a vida cometidos por militares contra civis passassem a ser julgados pelo Tribunal do Júri. Houve quem dissesse que a lei, ao transferir ao Júri a competência para julgamento de crimes militares, mostrava-se inconstitucional. Não pensamos assim, uma vez que a interpretação correta a ser dada, teleológica e não puramente gramatical, revela que a lei passou a considerar comuns esses delitos. Em outras palavras, não se trata de determinar 0 julgamento de crimes militares pela Justiça Comum, mas da modificação da natureza do delito, que de militar passou a ser considerado comum e, portanto, de competência da Justiça Comum (Estadual ou Federal). Note-se que o critério utilizado no Brasil para a definição de crimes militares é o ratione legis, isto é, considera-se crime militar aquele descrito pela lei como tal.

No âmbito jurisprudencial também há divergência sobre o assunto.

Vale dizer que a matéria foi questionada perante o Supremo Tribunal Federal através da Ação Direta de Inconstitucionalidade no 1494-DF. Entretanto, apesar de indeferir o pedido de medida cautelar, entendendo "que a norma inscrita no art. $82, \S 20$, do CPPM, na

${ }^{21}$ JESUS, Damasio Evangelista. Competência para julgamento de crime militar doloso contra a vida. Blogdamasio. Disponível em:<http://blog.damasio.com.br/?p=94>. Acesso em: 29 de dez. de 2015. 
GHIRALDELLI, Felipe Vittig. LEITE, Ruano Fernando da Silva. As atribuições de polícia judiciária no bojo das investigações de homicídios dolosos praticados por policiais militares contra civis. Revista Eletrônica Direito e Política, Programa de Pós-Graduação Stricto Sensu em Ciência Jurídica da UNIVALI, Itajaí, v.11, n.2, 2ㅇ quadrimestre de 2016. Disponível em: www.univali.br/direitoepolitica - ISSN 1980-7791.

redação dada pela Lei no 9299/96, reveste-se de aparente validade constitucional", não pôs fim ao conflito vez que não conheceu "da ação direta,por ausência de legitimidade ativa da ADEPOL" (Associação de Delegados da Polícia do Brasil).

O Superior Tribunal de Justiça no RHC 25.384/ ES 22, contudo, em acertado aresto já entendeu da seguinte forma:

(...) 1. A Lei 9.299/1996 incluiu o parágrafo único ao artigo $9^{\circ}$ do Código Penal Militar, consignando que os crimes nele tratados, quando dolosos contra a vida e praticados contra civil, são da competência da Justiça Comum.

2. O mesmo diploma legal acrescentou, ainda, um parágrafo no artigo 2 no Código de Processo Penal Militar, determinando que a Justiça Militar encaminhe os autos do inquérito policial militar à Justiça Comum, nos casos de crimes dolosos contra a vida cometidos contra

civil.

3. Diante de tais modificações, esta Corte Superior de Justiça adotou o entendimento de que, diante da incidência instantânea das normas processuais penais disposta no artigo $2^{\circ}$ do Código de Processo Penal, a Lei 9.299/1996 possui aplicabilidade a partir da sua vigência, de modo que todas as investigações criminais e processos em curso relativos a crimes dolosos contra a vida praticados por militar contra civil devem ser encaminhados à Justiça Comum. (...) (grifo nosso)

Ao apreciar este julgado, Bruno Taufner Zanotti23, esclarece que:

22 (STJ, RHC 25.384/ES, 5a T., rel. Min. Jorge Mussi, j. 7-12-2010, DJe 14-2-2011).

${ }^{23}$ ZANOTTI, Bruno Taufner. Homicídio cometido por policial militar contra civil: atribuição investigativa da polícia civil ou da polícia militar? Goias, 20 de novembro de 2013. Disponível em: <http://sindepol.com.br/site/artigos/homicidiocometido-por-policial-militar-contra-civil-tribuicao-investigativa-da-policia-civil-ouda-policia-militar.html>. Acesso 29 dezembro 2015. 
GHIRALDELLI, Felipe Vittig. LEITE, Ruano Fernando da Silva. As atribuições de polícia judiciária no bojo das investigações de homicídios dolosos praticados por policiais militares contra civis. Revista Eletrônica Direito e Política, Programa de Pós-Graduação Stricto Sensu em Ciência Jurídica da UNIVALI, Itajaí, v.11, n.2, 2ㅇ quadrimestre de 2016. Disponível em: www.univali.br/direitoepolitica - ISSN 1980-7791.

Pelo exposto, se houve a descaracterização do delito como crime militar, como é perfeitamente visível no julgado do STJ acima que resolveu conflito de competência, de modo a concluir pela competência do Tribunal do Júri; pelo mesmo motivo, a titularidade para a sua investigação compete à Polícia Civil. Afinal, como se observa pelo art. 144, §§ 40 e 50, da Constituição Federal, a Policia Militar somente investiga crimes militares, que não é a hipótese em tela.

E conclui que:

Por não ser hipótese de crime militar, por determinação constitucional, a investigação de tais crimes é atribuição em caráter indelegável da Polícia Civil. Entendimento em sentido contrário configuraria poderia caracterizar uma grave inadmissibilidade das provas produzidas pela Polícia Militar pelo Poder Judiciário (provas produzidas de forma contrária ao texto da Constituição), de modo a contribuir para a impunidade dos envolvidos.

O mesmo entendimento seguiu o Egrégio Tribunal de Santa Catarina através do RC $20130749889^{24}$, julgou favoravelmente a investigação realizada pela polícia civil:

RECURSO EM SENTIDO ESTRITO. HOMICÍDIO QUALIFICADO. CÓDIGO PENAL, ART. 121, § 2.0, I. PORTE ILEGAL DE ARMA DE FOGO COM NUMERAÇÃO SUPRIMIDA. LEI N. 10.826/03, ART. 16, PARÁGRAFO ÚNICO, IV. PRONÚNCIA. RECURSO DEFENSIVO.

PRELIMINAR. INÉPCIA DA DENÚNCIA. SUBSTRATOS PARA A FORMAÇÃO DAOPINIO DELICTI. PROCEDIMENTO REALIZADO PELA POLÍCIA CIVIL. ALEGAÇÃO DE INCOMPETÊNCIA. CRIME DOLOSO CONTRA A VIDA PRATICADO POR MILITARES CONTRA CIVIL. COMPETÊNCIA DA JUSTIÇA COMUM.

A competência para processar e julgar as ações relacionadas aos crimes dolosos contra a vida

24 TJ-SC - Recurso Criminal : RC 20130749889 SC 2013.074988-9. 
cometidos por militar contra civil, como no caso em apreço, é da justiça comum, conforme preceitua o art. 9.0, parágrafo único, do Código Penal Militar, o art.82, $\S 2.0$, do Código de Processo Penal Militar e o art. 125, $\S 4 .{ }^{\circ}$, da Constituição Federal, sendo, portanto, de competência da polícia civil presidir o inquérito policial. (grifo nosso)

Em verdade, não se descura do entendimento de que o vício da atribuição da autoridade policial não conduz à nulidade do processo penal. Entretanto, não se pode aceitar que cada Estado adote um procedimento ou mesmo que haja discricionariedade quanto à escolha da autoridade policial, especialmente quando se trata de distintas polícias com diferentes atribuições constitucionais.

Apesar do entendimento dos nobres doutrinadores citados anteriormente, diante das alterações normativas, a interpretação teleológica e mais consentânea com os direitos humanos somente pode conduzir ao entendimento de que a Constituição efetivamente modificou a natureza jurídica dos homicídios dolosos praticados por militares contra civis, transformando-os em delitos comuns.

Isto porque, na hipótese tratada aqui, não faz sentido atribuir a competência do Júri, visando afastar um julgamento com viés militar, e deixar que a investigação, a base da futura ação penal, seja feita pela Polícia Militar.

Não há dúvidas de que a ideia foi, sim, a de conceder às polícias Federal e Civil a atribuição para apurar as mortes de civis provocadas por militares, uma vez que praticadas em um Estado Democrático de Direito, ainda mais em tempos de paz. 
GHIRALDELLI, Felipe Vittig. LEITE, Ruano Fernando da Silva. As atribuições de polícia judiciária no bojo das investigações de homicídios dolosos praticados por policiais militares contra civis. Revista Eletrônica Direito e Política, Programa de Pós-Graduação Stricto Sensu em Ciência Jurídica da UNIVALI, Itajaí, v.11, n.2, 2ㅇ quadrimestre de 2016. Disponível em: www.univali.br/direitoepolitica - ISSN 1980-7791.

Especificamente no que concerne aos policiais militares, apesar de serem, como o próprio nome diz, militares, desempenham as suas funções de polícia ostensiva perante uma população civil e no enfrentamento de crimes comuns, não se justificando uma análise castrense da eventual conduta delitiva.

Vale salientar, ainda, que não é pelo fato de enfrentar uma criminalidade armada, agressiva e letal que se justifica a investigação e o processamento pela Justiça Militar, até porque os policiais federais, civis e rodoviários também a enfrentam e nem por isso são julgadas em uma corte especializada.

Também não convence o fraco argumento daqueles que defendem que a investigação pela Polícia Civil não levaria em consideração as dificuldades reais dos confrontos policiais, vez que a apuração pela polícia judiciária, federal ou civil, obviamente, não significa, por si só, prévio indiciamento.

Como exemplo, sem adentrar o mérito, relembre-se o polêmico "caso Cabula", no qual a investigação feita pela Polícia Civil do Estado da Bahia e a conclusão foi pelo não indiciamento dos policiais militares, o que foi corroborado pela absolvição levada a efeito posteriormente pela Justiça Estadual de primeiro grau 25 .

Deve-se acrescentar ainda que, eventualmente, poderá ser instaurado um inquérito policial militar para apurar outras condutas, porém essa possibilidade não poderá ser utilizada abusivamente para afastar a atribuição constitucional aqui defendida.

25 NOTÍCIAS PORTAL G1:

Em:<http://g1.globo.com/bahia/noticia/2015/07/decisao-afirma-legitimadefesa-de-pms-do-caso-cabula-mp-questiona.html>.Acesso em 16 outubro 2016. 

no bojo das investigações de homicídios dolosos praticados por policiais militares contra civis. Revista Eletrônica Direito e Política, Programa de Pós-Graduação Stricto Sensu em Ciência Jurídica da UNIVALI, Itajaí, v.11, n.2, 2ㅇ quadrimestre de 2016. Disponível em: www.univali.br/direitoepolitica - ISSN 1980-7791.

Em todo caso, o inquérito policial "civil" é a regra e deverá ser instaurado, prima facie, para apuração das mortes de civis, restando ao inquérito policial militar a excepcionalidade dos casos em que for constatada flagrantemente as hipóteses da competência militar, assim como determina o art. $10, \S 3^{\circ}$, do CPPM. Vejamos:

§ 30 Se a infração penal não fôr, evidentemente, de natureza militar, comunicará o fato à autoridade policial competente, a quem fará apresentar o infrator. Em se tratando de civil, menor de dezoito anos, a apresentação será feita ao Juiz de Menores.

Também é o que se extrai da Resolução nº 08, de 21 de dezembro de 2012, editada pela Secretaria de Direitos Humanos da Presidência da República, senão vejamos:

Art. 20 Os órgãos e instituições estatais que, no exercício de suas atribuições, se confrontarem com fatos classificados como "lesão corporal decorrente de intervenção policial" ou "homicídio decorrente de intervenção policial" devem observar, em sua atuação, o seguinte:

I -os fatos serão noticiados imediatamente a Delegacia de Crimes contra a Pessoa ou a repartição de polícia judiciária, federal ou civil, com atribuição assemelhada, nos termos do art. 144 da Constituição, que deverá:

a) instaurar, inquérito policial para investigação de homicídio ou de lesão corporal; (grifo nosso)

No mesmo sentido reverbera Castro ${ }^{26}$ ao dizer que:

${ }^{26}$ CASTRO, Henrique Hoffmann Monteiro de. Homicídio praticado por PM contra civil: atribuição da Polícia Civil. Revista Jus Navigandi, Teresina, ano 21, n. 4572, 7 jan. 2016. Disponível em:<https://jus.com.br/artigos/45635>. Acesso em: 15 janeiro 2016. 
GHIRALDELLI, Felipe Vittig. LEITE, Ruano Fernando da Silva. As atribuições de polícia judiciária no bojo das investigações de homicídios dolosos praticados por policiais militares contra civis. Revista Eletrônica Direito e Política, Programa de Pós-Graduação Stricto Sensu em Ciência Jurídica da UNIVALI, Itajaí, v.11, n.2, 2ㅇ quadrimestre de 2016. Disponível em: www.univali.br/direitoepolitica - ISSN 1980-7791.

Destarte, todo e qualquer miliciano suspeito da prática de crime contra a vida de vítima civil deve ser imediatamente apresentado ao Delegado de Polícia do lugar mais próximo (arts. 304 e 308 do CPP). Eventual condução de PM homicida a destacamento militar pode acarretar a responsabilização - inclusive penal - do comparsa que pretender favorecer 0 suspeito. A possibilidade de que o fato tenha sido praticado em legítima defesa não elide a exigência de apresentação do miliciano à Polícia Civil, porquanto a análise de eventual excludente de ilicitude incumbe ao Delegado de Polícia, e não ao oficial de Polícia Militar, agente da Autoridade Policial e ocupante de carreira não jurídica.

Ademais, saliente-se, as atribuições policiais investigativas são regidas pelos princípios da especialidade e da legalidade e seguem, obliquamente, a competência jurisdicional, salvo nas exceções legalmente justificadas como no caso da lei no 10.446/02. Na espécie, não há razão para que um mesmo fato seja investigado pela Polícia Militar e, posteriormente, julgado pela Justiça Comum, seria como criar um patiche como é bem colocado ao abordar o tema pelo consagrado Tourinho Filho27 :

Assim, aparentemente, essa nova lei apresenta
natureza
ou penal. Contudo, inegável sua natureza hibrida. No
que respeita aos crimes dolosos contra a vida,
consumados ou tentados, ela Ihes deu nova definição:
se cometidos contra militar, continuam sendo crimes
militares impróprios; se contra civis, passaram a ser
comuns. Assim, se um militar cometer um crime doloso
contra a vida de um civil pouco importando a natureza
do instrumento utilizado, se pertencente à Corporação,
ou não, responderá perante a Justiça Comum, levando-

27 TOURINHO FILHO, Fernando da Costa. Manual de Processo Penal. 15a Ed. São Paulo: Saraiva: 2012. p. 185. 
se em consideração, por razões óbvias, o Código Penal Comum. Não é pelo fato de o agente ser militar que, num homicídio contra civil, deva responder segundo o art. 205 do CPM, mas, sim, pelo art.121 do CP. Por outro lado, se o agente cometeu o crime prevalecendose da situação de serviço, não deve responder pela qualificadora prevista no art. 205, § 22 , VI, do CPM. O homicídio contra civil deixou de ser crime militar e, por isso mesmo, não pode a Justiça Comum fazer um verdadeiro pastiche, isto é, julgar um militar, segundo as normas do CPP Comum e do Código Penal Militar.

Assim, seguindo a razão da lógica jurídica, a persecução criminal na hipótese aqui delineada deve ficar apenas no âmbito civil. Seria inconcebível criar uma persecução com parte fundamentada no Código de Processo Castrense e a outra parte no Código de Processo Penal. Ora o investigado está sujeito às leis militares e ora está sujeito à lei civil.

De mais a mais, verifica-se que a investigação pela Polícia Militar não escapa de uma análise convencional.

\section{DO TRATAMENTO INTERNACIONAL SOBRE A QUESTÃO}

Em 1969, foi aprovada a Convenção Americana sobre Direitos Humanos que criou a Corte Interamericana de Direitos Humanos e definiu atribuições e procedimentos tanto da Corte como da Comissão. Ratificada por diversos países, inclusive o Brasil, a Convenção entrou em vigor, internacionalmente, em 1978.

Como é cediço, o Pacto de San José da Costa Rica é vinculante e, por ser um tratado internacional de direitos humanos, possui status de supralegalidade conforme definido pelo Supremo Tribunal Federal. Significa dizer que as suas normas são superiores às leis ordinárias, 
GHIRALDELLI, Felipe Vittig. LEITE, Ruano Fernando da Silva. As atribuições de polícia judiciária no bojo das investigações de homicídios dolosos praticados por policiais militares contra civis. Revista Eletrônica Direito e Política, Programa de Pós-Graduação Stricto Sensu em Ciência Jurídica da UNIVALI, Itajaí, v.11, n.2, 2ㅇ quadrimestre de 2016. Disponível em: www.univali.br/direitoepolitica - ISSN 1980-7791.

inclusive o Código de Processo Penal Militar, e inferiores à Constituição Federal.

Neste diapasão, leciona o Ministro Gilmar Mendes ${ }^{28}$ que:

Por fim, cabe registrar o encerramento do julgamento do Recurso Extraordinário n. 466.343 /SP, Rel. Min. Cezar Peluso, em 3-12-2008. Nessejulgado, o STF definiu a tese da supralegalidade dos tratados internacionais sobre direitos humanos que sejam internalizados pelo direito pátrio. Ou seja, foi superado o entendimento anterior - no sentido de que os tratados, ainda que versassem sobre direitos humanos, teriam a mesma estatura normativa das leis ordinárias - e prevaleceu, por maioria de votos, a tese de que os tratados internacionais de direitos humanos subscritos pelo Brasil possuem status supralegal, o que torna inaplicável a legislação infraconstitucional com eles conflitantes, seja ela anterior ou posterior ao ato de ratificação e que, desde a ratificação, pelo Brasil, sem qualquer reserva, do Pacto Internacional dos Direitos Civis e Políticos (art. 11) e da Convenção Americana sobre Direitos Humanos - Pacto de San José da Costa Rica (art. 70, §7).

E foi justamente em razão do descumprimento das normas convencionais que o Brasil sofreu denúncia na Comissão Interamericana de Direitos Humanos, dando origem ao caso Jailton Neri da Fonseca ${ }^{29}$ que versa sobre a execução do adolescente por policiais militares do Rio de Janeiro. Ao final, em seu relatório, a Comissão entendeu que:

28 MENDES, Gilmar Ferreira. BRANCO, Paulo Gustavo Gonet. Curso de Direito Constitucional. 10 $\mathrm{a}$ Ed. São Paulo: Saraiva: 2015. p. 172.

29 COMISSÃO INTERAMERICANA DE DIREITOS HUMANOS: Em: <https://www.cidh.oas.org/annualrep/2004sp/Brasil.11634.htm> Acesso 16 janeiro 2016 
GHIRALDELLI, Felipe Vittig. LEITE, Ruano Fernando da Silva. As atribuições de polícia judiciária no bojo das investigações de homicídios dolosos praticados por policiais militares contra civis. Revista Eletrônica Direito e Política, Programa de Pós-Graduação Stricto Sensu em Ciência Jurídica da UNIVALI, Itajaí, v.11, n.2, 2ㅇ quadrimestre de 2016. Disponível em: www.univali.br/direitoepolitica - ISSN 1980-7791.

102. Al respecto, la Comisión considera que la policía militar y los tribunales militares no tienen la independencia y autonomía necesarias para investigar ni para juzgar de manera imparcial las presuntas violaciones a los derechos humanos presuntamente cometidas por policías militares. Tanto la investigación de presuntas violaciones de derechos humanos realizada por la policía militar como el juzgamiento de dichas violaciones por tribunales militares, implican violación per se a los artículos $1.1,25$ y 8 de la Convención Americana.

No que concerne à Lei Rambo, a Comissão também reconheceu a óbvia incongruência oriunda da fixação da competência comum sem a retirada da atribuição da autoridade militar, inclusive com ofensa ao art. 144 da Constituição Federal. Veja:

Con esto, la investigación ("inquérito") permanecerá bajo la responsabilidad de la autoridad militar, aún cuando se trate de un crimen doloso contra la vida y a pesar de que, de acuerdo con la nueva ley, dichos crímenes pasan a la esfera de la Justicia común. Esta nueva disposición contradice el artículo 144, sección 4 de la Constitución, que asigna a las policías civiles las funciones de policía judicial y la investigación de las infracciones penales, excepto las militares. En efecto, si los crímenes dolosos contra la vida dejan de ser militares en virtud de la nueva ley, la investigación penal debería estar a cargo de las policías civiles, a las cuales corresponde, conforme al artículo 144, sección 4 de la Constitución, "las funciones de policía judicial y la investigación de las infracciones penales". Al dejar la investigación inicial en manos de la policía "militar", de hecho se confiere a ésta la competencia para determinar ab-initio si el crimen es doloso o no. Esto significa que la Ley 9.299 de la República no tiene capacidad efectiva para reducir significativamente la impunidad. 
GHIRALDELLI, Felipe Vittig. LEITE, Ruano Fernando da Silva. As atribuições de polícia judiciária no bojo das investigações de homicídios dolosos praticados por policiais militares contra civis. Revista Eletrônica Direito e Política, Programa de Pós-Graduação Stricto Sensu em Ciência Jurídica da UNIVALI, Itajaí, v.11, n.2, 2ㅇ quadrimestre de 2016. Disponível em: www.univali.br/direitoepolitica - ISSN 1980-7791.

Assim, conforme o trecho abaixo, concluiu a CIDH que resta inviável um julgamento objetivo por parte do Juízo comum quando a investigação é iniciada por uma autoridade militar:

117. La conclusión anterior no se ve modificada por el hecho de que la policía militar tenga a su cargo únicamente la investigación inicial, y que la competencia para juzgar haya sido atribuida a los tribunales del fuero penal ordinario. Ello debido a que la investigación del caso por parte de la policía militar brasileña, precluye la posibilidad de una investigación objetiva e independiente ejecutada por autoridades judiciales no ligadas a la jerarquía de mando de las fuerzas de seguridad. El hecho de que la investigación de un caso haya sido iniciada por la policía militar brasileña puede imposibilitar una condena aún si el caso pasa luego al fuero penal ordinario, dado que probablemente, debido a la falta de independencia e imparcialidad de la policía militar brasileña para investigar a sus propios agentes, la investigación y recolección inicial de pruebas se realiza generalmente con el propósito de dificultar el juzgamiento y tratar de garantizar la impunidad de los responsables de violaciones a los derechos humanos.

Ao final, a Comissão recomendou:

1. Reparar plenamente a los familiares de Jailton Neri da Fonseca, incluyendo tanto el aspecto moral como el material, por las violaciones de derechos humanos determinadas en el presente informe, y en particular,

2. Realizar una investigación completa, imparcial y efectiva de los hechos, por órganos que no sean militares, con el objeto de establecer y sancionar la responsabilidad respecto a los hechos relacionados con la detención y asesinato de Jailton Neri da Fonseca.

3. Indemnizar a los familiares de Jailton Neri da Fonseca tanto por los daños materiales como los daños morales sufridos con ocasión a su asesinato. Dicha reparación a ser pagada por el Estado brasileño, debe ser calculada conforme a los parámetros 
GHIRALDELLI, Felipe Vittig. LEITE, Ruano Fernando da Silva. As atribuições de polícia judiciária no bojo das investigações de homicídios dolosos praticados por policiais militares contra civis. Revista Eletrônica Direito e Política, Programa de Pós-Graduação Stricto Sensu em Ciência Jurídica da UNIVALI, Itajaí, v.11, n.2, 2ㅇ quadrimestre de 2016. Disponível em: www.univali.br/direitoepolitica - ISSN 1980-7791.

internacionales, y debe ser por un monto suficiente para resarcir tanto los daños materiales como los daños morales sufridos por los familiares de Jailton Neri da Fonseca con ocasión de su asesinato y demás violaciones a sus derechos humanos a que se refiere este informe.

4. Modificar el artículo 9 del Código Penal Militar, el artículo 82 del Código de Procedimiento Penal Militar y cualquier otra norma interna que requiera modificarse a los efectos de abolir la competencia de la policía militar para investigar violaciones a derechos humanos cometidas por policías militares, y transferir dicha competencia a la policía civil.

5. Adoptar e instrumentar medidas de educación de los funcionarios de justicia y de la policía, al fin de evitar acciones que implique en discriminación racial en los operativos policiales, en las investigaciones, en el proceso o en la condena penal.

6. Adoptar e instrumentar acciones inmediatas para asegurar el cumplimiento de los derechos establecidos en la Convención Americana, en la Convención sobre los Derechos del Niño y en las demás normas nacionales e internacionales concernientes al tema, de manera que se haga efectivo el derecho a protección especial de la niñez en Brasil.

Importante ressaltar que, em 2009, o Brasil realizou o pagamento da indenização pecuniária e formalizou, através do Estado do Rio de Janeiro, o pedido publico de desculpas ${ }^{30}$. Entretanto, verifica-se que houve apenas o cumprimento parcial da recomendação, razão pela qual o País ainda encontra-se em mora com as suas obrigações internacionais.

\section{CONSIDERAÇÕES FINAIS}

\footnotetext{
30 COMISSÃO INTERAMERICANA DE DIREITOS HUMANOS: Em: <https://www.cidh.oas.org/annualrep/2004sp/Brasil.11634.htm> Acesso 16 janeiro 2016
} 

no bojo das investigações de homicídios dolosos praticados por policiais militares contra civis. Revista Eletrônica Direito e Política, Programa de Pós-Graduação Stricto Sensu em Ciência Jurídica da UNIVALI, Itajaí, v.11, n.2, 2ㅇ quadrimestre de 2016. Disponível em: www.univali.br/direitoepolitica - ISSN 1980-7791.

De fato, ainda persiste o conflito de atribuição em relação a investigação de homicídios dolosos praticados por policiais militares contra vítimas civis.

De um lado, com fortes argumentos e alicerçados em uma interpretação literal, doutrinadores, instituições e operadores defendem que os fatos devem ser investigados através de um Inquérito Policial Militar, presidido por uma autoridade da própria Polícia Militar.

Por outro lado, diversos doutrinadores posicionam-se contrariamente à continuidade das investigações por militares, sufragados por uma interpretação teleológica e constitucional.

Como se verificou, entretanto, além das alterações legais e constitucionais evidenciarem uma opção por uma investigação civil, já existe determinação da Comissão Interamericana de Direitos Humanos no sentido de que o Brasil modifique a legislação para "abolir a competência da polícia militar para investigar violações a direitos humanos cometidas por policiais militares, e transferir a referida competência para a polícia civil"31.

Por estas razões, entende-se que não é mais possível admitir a investigação de homicídios praticados por policiais militares em detrimento de vítimas civis, cabendo tal atribuição exclusivamente às polícias judiciárias, Federal e Civil, conforme as determinações constitucionais e convencionais.

\section{REFERÊNCIAS DAS FONTES CITADAS}

31 Livre tradução 

Jurídica da UNIVALI, Itajaí, v.11, n.2, 2ㅇ quadrimestre de 2016. Disponível em: www.univali.br/direitoepolitica - ISSN 1980-7791.

ASSIS, Jorge Cesar de. Aspectos penais e processuais penais e administrativos. 2ª Ed. Curitiba: Juruá, 2007.

BUSATO, Paulo César. Direito Penal: parte especial 1. São Paulo: Atlas, 2014.

CASTRO, Henrique Hoffmann Monteiro de. Homicídio praticado por PM contra civil: atribuição da Polícia Civil. Revista Jus Navigandi, Teresina, ano 21, n. 4572, 7 jan. 2016. Disponível em:<https://jus.com.br/artigos/45635>. Acesso em: 15 janeiro 2016.

FERNANDeS, Antonio Scarance. Processo Penal Constitucional. São Paulo: Revista dos Tribunais, 2005.

GRECO, Rogério. Curso de Direito Penal: parte especial II. $11^{\mathrm{a}}$ Ed. Niterói: Impetus, 2015.

JESUS, Damasio Evangelista. Competência para julgamento de crime militar doloso contra a vida. Blogdamasio. Disponível em:<http://blog.damasio.com.br/?p=94>. Acesso em: 29 de dez. de 2015.

LENZA, Pedro. Direito Constitucional Esquematizado.16a Ed. São Paulo: Saraiva. 2013.

LIMA. Renato Brasileiro. Manual de Processo Penal. $3^{\mathrm{a}} \mathrm{Ed}$. Salvador: Juspodivm, 2015.

LOBÃO, Célio. Comentários ao Código Penal Militar: Vol. 1 Parte Geral. Rio de Janeiro: Forense, 2011. 

no bojo das investigações de homicídios dolosos praticados por policiais militares contra civis. Revista Eletrônica Direito e Política, Programa de Pós-Graduação Stricto Sensu em Ciência Jurídica da UNIVALI, Itajaí, v.11, n.2, 2ㅇ quadrimestre de 2016. Disponível em: www.univali.br/direitoepolitica - ISSN 1980-7791.

MARCÃo, RenATO. Curso de Processo Penal. São Paulo: Saraiva. 2014.

MENDES, Gilmar Ferreira. BRANCO, Paulo Gustavo Gonet. Curso de Direito Constitucional. 10a Ed. São Paulo: Saraiva: 2015.

PEREIRA, Jeferson Botelho. Crimes dolosos contra a vida cometidos por militares contra civis. Minas Gerais, 23 de março de $2009 . \quad$ Disponível em: <http://www.jefersonbotelho.com.br/crimes-dolosos-contra-a-vidacometidos-por-militares-contra-civis>. Acesso em: 15 janeiro 2016

ZANOTTI, Bruno Taufner. Homicídio cometido por policial militar contra civil: atribuição investigativa da polícia civil ou da polícia militar? Goias, 20 de novembro de 2013. Disponível em: <http://sindepol.com.br/site/artigos/homicidio-cometido-por-policialmilitar-contra-civil-tribuicao-investigativa-da-policia-civil-ou-dapolicia-militar.html>. Acesso 29 dezembro 2015.

TÁVORA, Nestor; ALENCAR, Rosmar Rodrigues. Curso de Direito Processual Penal. 9a Ed. Salvador: Juspodivm, 2014.

TOURINHO Filho, Fernando da Costa. Manual de Processo Penal. 15ª Ed. São Paulo: Saraiva: 2012.

Submetido em: Fevereiro de 2016.

Aprovado em: Junho de 2016. 